\title{
Exogenous $\beta$-mannanase improves feed conversion efficiency and reduces somatic cell count in dairy cattle
}

\author{
T. A. Tewoldebrhan, ${ }^{*}$ J. A. D. R. N. Appuhamy, ${ }^{*}$ J.-J. Lee,† M. Niu, ${ }^{*}$ S. Seo,‡ S. Jeong, $\ddagger$ and E. Kebreab*1 \\ *Department of Animal Science, University of California, Davis 95616 \\ †CTCBio Inc., Seoul, Republic of Korea 05842 \\ †Department of Animal Biosystem Sciences, Chungnam National University, Daejeon 305-764, Republic of Korea
}

\begin{abstract}
Exogenous fibrolytic enzymes have been shown to be a promising way to improve feed conversion efficiency (FCE). $\beta$-Mannanase is an important enzyme digesting the polysaccharide $\beta$-mannan in hemicellulose. Supplementation of diets with $\beta$-mannanase to improve FCE has been more extensively studied in nonruminants than in ruminants. The objective of this study was to investigate the effects of $\beta$-mannanase supplementation on nutrient digestibility, FCE, and nitrogen utilization in lactating Holstein dairy cows. Twelve post-peaklactation multiparous Holstein cows producing $45.5 \pm$ $6.6 \mathrm{~kg} / \mathrm{d}$ of milk at $116 \pm 19.0 \mathrm{~d}$ in milk were randomly allotted to 1 of 3 treatments in a $3 \times 3$ Latin square design with 3 periods of $18 \mathrm{~d}$ ( $15 \mathrm{~d}$ for adaptation plus $3 \mathrm{~d}$ for sample collection). All cows were fed the same basal diet and the 3 treatments differed only by the $\beta$-mannanase dose: $0 \%$ dry matter (DM; control), $0.1 \%$ of DM (low supplement, LS), and $0.2 \%$ of DM (high supplement, HS) supplemented to the basal diet. Supplementation of $\beta$-mannanase enzyme at the LS dose reduced dry matter intake (DMI) but did not affect milk yield or milk composition. Cows receiving LS produced $90 \mathrm{~g}$ more milk per $\mathrm{kg}$ of DMI compared with control cows. Somatic cell count (SCC) in milk was lower for cows fed the LS diet compared with cows fed control diets. Cows fed LS diet had lower DM, organic matter and crude protein digestibility compared with cows fed control diets. Starch, neutral detergent fiber, and acid detergent fiber digestibility were not affected by LS. Milk yield, DMI, SCC, and nutrient digestibility did not change for HS. Despite the reduced crude protein digestibility, reduced $\mathrm{N}$ intake led to similar fecal $\mathrm{N}$ excretions in LS cows and control cows (234 vs. 235 $\mathrm{g}$ /cow per day). Urinary $\mathrm{N}$ excretions remained similar between enzyme-fed and control cows $(\sim 190 \mathrm{~g} /$ cow per day), although the percentage of $\mathrm{N}$ intake partitioned
\end{abstract}

Received February 10, 2016.

Accepted September 10, 2016.

${ }^{1}$ Corresponding author: ekebreab@ucdavis.edu to urinary $\mathrm{N}$ tended to be greater in LS than in control cows (31 vs. 27\%). Cows fed LS significantly improved the percentage of apparently absorbed $\mathrm{N}$ partitioned to milk protein N (42 vs. $38 \%$ ). When supplemented at $0.1 \%$ of dietary DM, $\beta$-mannanase can improve FCE and lower the SCC of dairy cows without affecting milk yield, milk composition, or total manure $\mathrm{N}$ excretions of dairy cows.

Key words: $\beta$-mannanase, feed conversion efficiency, lactating cows, somatic cell count

\section{INTRODUCTION}

Improving feed conversion efficiency (FCE), which is the amount of product (e.g., milk yield) per unit of feed consumed, has a positive economic and environmental impact on a dairy enterprise. For example, within certain limits, greater inclusion of nonstructural carbohydrates in diets is often associated with greater milk yield per unit of DMI compared with diets with greater structural carbohydrates (Lascano et al., 2011). Increasing intake of available energy through improvement of fiber digestibility by exogenous fibrolytic enzymes can improve FCE. Although a considerable number of studies have shown increased milk production and ADG in ruminants, others did not observe improvement in FCE by using exogenous fibrolytic enzymes (Beauchemin et al., 2003). Exogenous xylanases and cellulases are the most commonly used fibrolytic enzymes for ruminants (Mendoza et al., 2014). Exogenous xylanase have been shown to increase total-tract digestibility of DM, NDF, and ADF in cattle (Yang et al., 2000), indicating that endogenous enzyme secretions in the rumen could be limiting, inefficient, or both, in attacking the substrate polysaccharides as target glycosidic bonds can be inaccessible to the active site of the enzymes (Boraston et al., 2004).

The polysaccharide $\beta$-mannan is an important component of the plant cell walls and can be classified into 4 groups: pure mannan, glucomannan, galactomannan, and galactoglucomannan (Moreira and Filho, 2008). Each of these plant cell wall polysaccharides present a 
backbone of $\beta$-1,4-linked mannose and glucose residues substituted with side chains of $\alpha-1,6$-linked galactosyl side groups (Dea and Morrison, 1975). In contrast, a series of oligosaccharides containing $\alpha-1,2, \alpha-1,3$, and $\alpha-1,6$ linkages have been isolated from yeast mannan. The mannosidic bonds in the $\beta$-mannans are hydrolyzed by $\beta$-mannanases found in glycoside hydrolase $(\mathbf{G H})$ families 5 and 26 (Tailford et al., 2009), which also include cellulases and xylanases. Moreover, $\beta$-mannanases use mechanisms similar to those used by celluloses and xylanases in identifying and accessing the substrate (Sunna et al., 2001; Boraston et al., 2004). Hydrolysis of the $\beta$-mannans by $\beta$-mannanase releases mannanoligosaccharides (MOS) of various lengths (Franco et al., 2004). Dietary supplementation of MOS has been shown to improve gastrointestinal health or overall health and performance of broilers (Yang et al., 2008), dogs (Swanson et al., 2002), and dairy calves (Heinrichs et al., 2003). Feeds containing high concentrations of $\beta$-mannan are palm kernel meal (30-35\% of DM), palm kernel expeller ( $24 \%$ of DM), soybean hull ( $8 \%$ of DM), soybean meal (2\% of DM) and sesame meal (3\% of DM) (Dierick, 1989; Mok et al., 2013).

Saenphoom et al. (2013) reported the hemicellulose content of palm kernel expeller to decrease by $26 \%$ after treatment with $\beta$-mannanase. Lawal et al. (2010) reported that $\beta$-mannanase extracts from Aspergillus niger significantly increased hemicellulose digestibility in broilers fed palm kernel cake-based diets. Daskiran et al. (2004) reported that $\beta$-mannanase improved feed to gain ratio in broilers fed diets with soybean meal and guar gum. The effect of $\beta$-mannanase on FCE increased as guar gum content increased (Daskiran et al., 2004). Supplementation of $\beta$-mannanases has been shown to improve gain to feed ratios in pigs and broilers (Pettey et al., 2002; Kong et al., 2011; Cho and Kim, 2013; Lv et al., 2013) and feed digestibility in broilers, layers, and pigs (Wu et al., 2005; Kong et al., 2011; Mussini et al., 2011; Kim et al., 2013; Mok et al., 2013). However, greater FCE is not always related to digestibility improvements. Gharaei et al. (2012) and Zangiabadi and Torki (2010) demonstrated improvements in immune status parallel to increasing FCE in broilers for $\beta$-mannanase supplementations.

There is a paucity of information on $\beta$-mannanase produced by rumen bacteria. Nakai et al. (1994) examined degradation of $\beta$-mannan in the cultures of 26 strains of 9 species of rumen bacteria and found only 5 strains that degraded more than $20 \%$ of the $\beta$-mannan in culture media. About $80 \%$ of the strains were $\mathrm{Bu}$ tyrivibrio fibrisolvens. Fernando et al. (2010) showed that ruminal Butyrivibrio fibrisolvens populations declined by about 10-fold as the forage to concentrate ratio changed from 100:0 to 60:40 in cattle. Therefore, exogenous $\beta$-mannanase may enhance degradation of $\beta$-mannan in the rumen, when cows are fed total mixed rations containing high-mannan feeds such as palm kernel meal and soybean hulls. However, a recent study by Lee et al. (2014) showed no changes in total-tract CP or NDF digestibility in 6 -mo-old goats for $\beta$-mannanase supplementation, even though it improved ADG, FCE, and $\mathrm{N}$ retention. Arndt et al. (2015) demonstrated that dairy cows with greater FCE were associated with lower SCC and greater N partitioning to milk protein compared with cows with lower FCE. The objective of this study was to investigate the effects of exogenous $\beta$-mannanase supplementation on nutrient digestibility, FCE, SCC, and N partitioning in lactating dairy cows.

\section{MATERIALS AND METHODS}

\section{Animals and Treatments}

All animal procedures were approved by Institutional Animal Care and Use Committee at the University of California-Davis. The experiment was conducted at the Teaching and Research Facilities of the Department of Animal Science at the University of California-Davis. Twelve post-peak-lactation multiparous Holstein cows with an average of $696 \pm 47 \mathrm{~kg}$ of BW, $45.5 \pm 6.6 \mathrm{~kg} / \mathrm{d}$ of milk yield, and $116 \pm 19.0$ DIM at the beginning of the experiment were housed in a freestall barn equipped with Calan gates (American Calan, Northwood, NH). Cows were assigned to 3 treatments in a 3 -period crossover design, where treatment sequences were balanced using $3 \times 3$ Latin squares to mitigate possible carryover effects. The treatments were a basal TMR diet only or supplemented with 2 doses of a commercially available $\beta$-mannanase enzyme (CTCZYME, patent 100477456 0000; CTC Bio Inc., Seoul, South Korea). The CTCZYME product contains pure $\beta$-mannanase, which is produced using a gene encoding mannanase of Bacillus subtilis WL-7 cloned into Escherichia coli. The mannanase gene encodes a polypeptide of 362 amino acids, the sequence of which is highly homologous to those of mannanases belonging to GH family 26 . Kweun et al. (2004) reported that the enzyme had a $\mathrm{pH}$ optimum at 6.0 and a temperature optimum at $55^{\circ} \mathrm{C}$. The activity of the enzyme was estimated to be $800,000 \mathrm{U} / \mathrm{kg}$ at $\mathrm{pH}$ 4.0 and $30^{\circ} \mathrm{C}$ (Kim et al., 2013). The enzyme was active on mannan sources such as locust bean gum, konjak, and guar gum, and it did not exhibit activity toward yeast mannan, carboxymethylcellulose, $\beta$-glucan, or xylan. The CTCZYME $\beta$-mannanase was previously tested in broilers (Kong et al., 2011; Mussini et al., 2011; Ferreira et al., 2016), pigs (Yoon et al., 2010; Kim et al., 2013), goats (Lee et al., 2014), and growing heifers (Seo et al., 2016). The enzyme product is available in 
powder form and is not soluble in water. In the present study, the $\beta$-mannanase enzyme was supplemented at 0 (control), $0.1 \%$ of DM (low supplementation rate, LS), and $0.2 \%$ of DM (high supplementation rate, HS). The doses were determined based on the study by Lee et al. (2014), who demonstrated improved FCE at 0.06 and $0.17 \%$ of DM in 6 -mo-old goats.

Ingredient and chemical composition of the basal diet are given in Table 1 . The enzyme was offered to the animals by hand mixing it ( $\sim 27$ to $54 \mathrm{~g} /$ cow per day) thoroughly with corn silage $(\sim 20 \mathrm{~kg}$ as-fed/cow per day) first and then mixing the corn silage with rest of the feed. Mixing $\beta$-mannanase in a similar manner; that is, without using water as a carrier, has been shown to improve animal performance previously (Lee et al., 2014; Seo et al., 2016). Each experimental period lasted $18 \mathrm{~d}$, consisting of $14 \mathrm{~d}$ for adaptation in the freestall barn, $1 \mathrm{~d}$ for adaptation to metabolic stalls, and $3 \mathrm{~d}$ for total collection of urine and feces from cows housed individually in metabolic stalls. Each metabolic stall was equipped with a feed trough, a water cup, and a rubber floor. Cows in the freestall barn and metabolic stalls were fed twice daily at 0800 and $2000 \mathrm{~h}$ at $105 \%$ of previous day intake. Milk yield and composition and DMI of individual animals were measured in both the freestall barn and metabolic stalls. All animals had free access to water at all times.

\section{Sample Collection and Analysis}

Feed offered to and refused by individual cows was weighed and recorded daily. Orts from individual cows were sampled daily in each period. Individual feed ingredients were sampled just before (on d 13) and at the end (on d 18) of sampling in each period. Feed ingredients and orts samples of individual cows were pooled by days within each period and stored at $-20^{\circ} \mathrm{C}$ until analyzed for chemical composition. Cows were milked twice daily at 0600 and $1800 \mathrm{~h}$. Milk samples were collected daily from individual cows and stored at $4^{\circ} \mathrm{C}$ until analyzed for milk fat, protein, lactose, MUN concentrations, and milk SCC (Central Counties DHIA, Atwater, CA).

Daily feces and urine output by individual cows $(\mathrm{kg} / \mathrm{d})$ in metabolic stalls were measured on d 16 through d 18 as described by Niu et al. (2016). We assumed that digestion and metabolic responses to enzyme would reach homeostasis after a 2 -wk adaptation period. A similar procedure described by Niu et al. (2016) was able to capture most of the expected digestibility and $\mathrm{N}$ partitioning response changes for dietary modifications when analyzed with mixed-effect models accounting for variability of individual cows (nested in treatment sequence). Feces from individual cows were scraped with long hoe scrapers into a plastic tray assigned to each cow before they stepped or rested on it. The individual feces trays were weighed and a representative feces sample (100 to $150 \mathrm{~g}$ ) was drawn every $3 \mathrm{~h}$ during the metabolic trial period. Fecal samples pooled within each day of each period were stored at $-20^{\circ} \mathrm{C}$ until analyzed for chemical composition. Urine from each cow was collected using an indwelling Foley catheter (24 French, 75-mL balloon; C. R. Bard, Covington, GA) connected to a $\sim 2$ - to 3 -m-long Tygon tube (Fisher Scientific, Waltham, MA) running into a sterile plastic jar (Fisher Scientific). Urine catheters were installed immediately after cows had been moved to metabolic stalls (0800 to $1000 \mathrm{~h}$ ). Sample collection began after a 24-h acclimatization period. Cows were calm with no obvious vocalizations or restlessness after the catheters had been installed. All urine cans were weighed, sampled, and emptied every $6 \mathrm{~h}(0800,1400,2000$, and $0200 \mathrm{~h}$ ). A $5-\mathrm{mL}$ aliquot of urine was pipetted into a $250-\mathrm{mL}$ plastic bottle containing $180 \mathrm{~mL}$ of $0.5 \mathrm{~mol} / \mathrm{L}$ sulfuric acid at each time of sampling. Acidified urine samples were stored at $-20^{\circ} \mathrm{C}$ until analyzed for total $\mathrm{N}$ concentration. Feed ingredients and orts samples were analyzed for $\mathrm{DM}\left(135^{\circ} \mathrm{C}\right.$, AOAC International, 2000; method 930.15), CP $(6.25 \times$ Kjeldahl N, AOAC International, 2000; method 990.03), NDF (Van Soest et al., 1991), ADF (AOAC International, 2000; method 973.18), lignin (Goering and Van Soest, 1970), starch (Hall, 2009, with correction for free glucose), total ash

Table 1. Ingredients and chemical composition of the basal experimental diet (\% of DM)

\begin{tabular}{lc}
\hline Item & Value \\
\hline Ingredient $^{1}$ & \\
Corn silage $^{2}$ & 33.2 \\
Alfalfa hay $^{2}$ & 26.9 \\
Steam-flaked corn & 10.4 \\
Distillers grain & 6.2 \\
Soybean meal & 6.2 \\
Rolled barley & 4.1 \\
Mineral mix & 1.3 \\
Soybean hulls & 7.3 \\
Cotton seed & 4.1 \\
Calcium carbonate & 0.10 \\
Salt (NaCl) & 0.12 \\
B-Mannanase & 0.0 \\
Chemical composition & \\
DM & 68.1 \\
CP & 16.8 \\
ADF & 24.6 \\
NDF & 35.9 \\
Lignin & 4.4 \\
Starch & 20.2 \\
Ether extract & 4.0 \\
\hline Contained & $30.9 \%$
\end{tabular}

${ }^{1}$ Contained $46 \% \mathrm{DM}$ and $8.1 \% \mathrm{CP}, 39.9 \% \mathrm{NDF}$, and $30.9 \%$ starch on DM basis.

${ }^{2}$ Contained $87.3 \% \mathrm{DM}$ and $24 \% \mathrm{CP}, 33.8 \% \mathrm{NDF}$, and $2.8 \%$ starch on DM basis. 
$\left(535^{\circ} \mathrm{C}\right.$, AOAC International, 2000; method 942.05), and individual mineral contents (AOAC International, 2000) at Cumberland Valley Analytical Services Inc. (Maugansville, MD). Dried and ground fecal samples (1.0-mm screen) were analyzed for the same chemical composition as the feeds at Cumberland Valley Analytical Services Inc. The urine samples were analyzed for total N (Chen et al., 1992) at Penn State University (State College, PA).

\section{Calculations and Statistical Analysis}

Apparent total-tract digestibility (ATTD, \%) of DM, $\mathrm{OM}, \mathrm{CP}, \mathrm{NDF}, \mathrm{ADF}$, and starch were calculated using fecal output $(\mathrm{F}, \mathrm{kg} / \mathrm{d})$ and corresponding intake (I, $\mathrm{kg} / \mathrm{d}$ ) of the nutrient:

$$
\operatorname{ATTD}=(\mathrm{I}-\mathrm{F} / \mathrm{I}) \times 100 .
$$

The nutrient intake was calculated by accounting for offered feed DM (OF, $\mathrm{kg} / \mathrm{d})$ and concentration of the nutrient in offered feed (OFc, \% DM), and refused feed $\mathrm{DM}(\mathrm{RF}, \mathrm{kg} / \mathrm{d})$ and concentration of the nutrient in refused feed (RFc, \% DM):

$$
\mathrm{I}=(\mathrm{OF} \times \mathrm{OFc} / 100)-(\mathrm{RF} \times \mathrm{RFc} / 100) .
$$

Apparently absorbed $\mathrm{CP}$ and $\mathrm{OM}$ flows $(\mathrm{kg} / \mathrm{d})$ were calculated by taking the difference between corresponding intake and fecal output. Feed conversion efficiencies were expressed as milk yield to DMI ratio (milk:DMI), milk yield to apparently absorbed OM ratio, and milk protein yield to dietary $\mathrm{CP}$ intake ratio. Nitrogen partitioning was calculated by expressing $\mathrm{N}$ in feces, urine and milk, and retained $\mathrm{N}$ as a percentage of $\mathrm{N}$ intake.

Effects of $\beta$-mannanase supplementation on intake and digestibility, milk yield and composition, FCE, and $\mathrm{N}$ partitioning were determined using the MIXED procedure of SAS (version 9.4, SAS Institute Inc., Cary, $\mathrm{NC}$ ) according to the following model:

$$
\mathrm{Y}_{\mathrm{ijkl}}=\mu+\mathrm{T}_{\mathrm{i}}+\mathrm{P}_{\mathrm{j}}+\mathrm{S}_{\mathrm{k}}+\mathrm{C}_{\mathrm{l}}\left(\mathrm{S}_{\mathrm{k}}\right)+\mathrm{e}_{\mathrm{ijk} \mathrm{k}}
$$

where $Y_{\mathrm{ijkl}}=$ the response variable of interest, $\mu=$ overall mean, $\mathrm{T}_{\mathrm{i}}=$ fixed effect of ith treatment $(\mathrm{i}=$ control, LS, and HS), $\mathrm{P}_{\mathrm{j}}=$ fixed effect of $\mathrm{jth}$ period $(\mathrm{j}$ $=1$ to 3$), \mathrm{S}_{\mathrm{k}}=$ random effect of kth treatment sequence $(\mathrm{k}=1$ to 3$), \mathrm{C}_{\mathrm{l}}\left(\mathrm{S}_{\mathrm{k}}\right)=$ random effect of lth cow nested in kth treatment sequence, and $\mathrm{e}_{\mathrm{ijkl}}=$ random error assumed to be independent and identically distributed from a normal distribution with a mean of 0 and a variance of $\sigma^{2}\left[\sim N\left(0, \mathrm{I} \sigma^{2}\right)\right]$. Period $\times$ treatment interactions were initially included and found to be nonsig- nificant, and were subsequently excluded in the final analyses. Pair-wise comparisons of treatments means (control vs. LS, control vs. HS, and LS vs. HS) were carried out with the Tukey-Kramer adjustment test. Somatic cell counts were log-transformed for use in the statistical analysis, as the absolute counts $\left(\times 10^{3} / \mathrm{mL}\right)$ were not normally distributed. The least squares means values were transformed back to absolute counts (as shown in tables). Statistical differences were declared at $P<0.05$, and a tendency toward significance was considered at $0.05<P<0.10$.

\section{RESULTS AND DISCUSSION}

\section{Feed Intake, Milk Yield, and SCC}

Dry matter intake, milk yield, and milk composition responses to $\beta$-mannanase supplementation are given in Table 2. Dry matter intake decreased significantly by $1.8 \mathrm{~kg} / \mathrm{d}(23.3$ vs. $25.1 \mathrm{~kg} / \mathrm{d} ; P<0.001)$ at low dose (LS) but remained similar to control at high dose (HS). Regardless of the dose, cows receiving $\beta$-mannanase consumed less than cows not receiving the enzyme $(P=$ 0.001). Reduced DMI was not observed in other studies that used the present $\beta$-mannanase enzyme product in broilers, pigs, goats, or growing heifers (Kong et al., 2011; Kim et al., 2013, Lee et al., 2014, and Seo et al., 2016, respectively). Milk yield, milk composition, and milk component yields did not differ significantly with enzyme supplementations. This is the first study to examine the effect of $\beta$-mannanase on milk production. Other exogenous enzymes such as xylanase also targeting hemicellulose polysaccharides did not affect milk yield or composition (Romero et al., 2016). Somatic cell count in milk decreased in cows fed the LS $\operatorname{diet}(P=0.043)$ but not the HS diet. The majority of cells in SCC are white blood cells such as macrophages, lymphocytes, and neutrophils, which fight against udder infections and repair damaged tissues (Bradley and Green, 2005; Yu et al., 2011). Although SCC may not be as sensitive as bacterial culture in identifying infected quarters (Middleton et al., 2004), ease of measurement and its reasonably strong relationship with total viable bacterial counts in milk make SCC an effective udder health indicator (Kasikci et al., 2012). Although cows having SCC >200,000 cells/mL are usually considered to have subclinical mastitis, a recent study by Nyman et al. (2016) demonstrated that the SCC cut-off to classify cows as having intramammary infections can be as low as 74,000 cells $/ \mathrm{mL}$. At the cow level, SCC is a reduced representation of the true inflammation because infection occurs at the quarter level (Bradley and Green, 2005). Therefore, an average SCC decreasing from 72,000 to 59,000 cells $/ \mathrm{mL}$ could indicate that 
exogenous $\beta$-mannanase shifted cows from close to subclinical mastitis to a reasonably healthy status.

Somatic cell count in milk can vary significantly due to other factors such as stage of lactation and parity regardless of whether cows are infected (Sharma et al., 2011). Yu et al. (2011) indicated that the progressive increases of SCC when parity increased might be related to other mechanisms stimulating the immune system in the absence of infections. Besides innate immunity-related responses such as elevated neutrophil percentages and production of tumor necrosis factor- $\alpha$ (TNF- $\alpha$ ) and IL-1 $\beta$ (Oviedo-Boyso et al., 2007), SCC are positively related to adaptive immunity-related production of IL-17 and IFN- $\gamma$ by bovine T lymphocytes (Rainard et al., 2015, 2016). Although previous studies using the $\beta$-mannanase product used in the current study did not look into the effects on immune responses, supplementation of $\beta$-mannanase from other sources has been shown to have such an effect. Improvements in health status for supplementation of $\beta$-mannanase or MOS in nonruminant species have been reported widely. In a study using broiler chicks, Jackson et al. (2003) reported that supplementation of $\beta$-mannanase significantly increased weight gain and reduced both upper and lower coccidial lesion scores in birds infected with Eimeria sp. or Clostridium perfringens. Ibuki et al. (2014) reported that MOS (e.g., $\beta$-1,4-mannobiose) supplemented with mannanase-hydrolyzed copra meal exerted anti-inflammatory effects such as decreasing the expression of TNF- $\alpha$, IL-1 $\beta$, and IL-17 in the colon of pigs suffering from intestinal inflammation. Moreover, Che (2010) indicated that dietary inclusion of MOS in diets for pigs could maintain the host's disease resistance while preventing overstimulation of the immune system. Therefore, the observed reduction in SCC is likely linked to a situation where the immune system responded optimally to inflammation in the mammary gland as mediated by MOS liberated via $\beta$-mannanaseinduced hydrolysis of $\beta$-mannan in cows. The hydrolysis of $\beta$-mannan may also play a role in controlling the immune responses. The cellular component of innate immune system (e.g., neutrophils and macrophages) identifies pathogens using distinct molecules; namely, pathogen-associated molecular patterns (PAMP) expressed on the surface of pathogens (Forsberg and Wang, 2006). Binding of these PAMP to receptors present on the surface of innate immune cells activate those cells (Forsberg and Wang, 2006) and may stimulate their proliferation (Egger et al., 1996). Because PAMP include sugar residues such as mannans, $\beta$-mannan in feeds such as soybean hull can create a false signal of the presence of pathogens in the gut, initiating unwarranted immune responses. The $\beta$-mannanase-induced hydrolysis of $\beta$-mannan can eliminate such a signal and
Table 2. Effects of $\beta$-mannanase supplementation on DMI, milk production, and milk composition of dairy cows

\begin{tabular}{|c|c|c|c|c|}
\hline \multirow[b]{2}{*}{ Item } & \multicolumn{3}{|c|}{ Treatment $^{1}$} & \multirow[b]{2}{*}{ SEM } \\
\hline & Control & LS & HS & \\
\hline$\overline{\mathrm{DMI}}(\mathrm{kg} / \mathrm{d})$ & $25.1^{\mathrm{a}}$ & $23.3^{\mathrm{b}}$ & $24.3^{\mathrm{ab}}$ & 0.66 \\
\hline \multicolumn{5}{|l|}{ Yield (kg/d) } \\
\hline Milk & 34.4 & 34 & 34.8 & 1.63 \\
\hline Milk fat & 1.31 & 1.25 & 1.33 & 0.08 \\
\hline Milk protein & 1.05 & 1.04 & 1.07 & 0.05 \\
\hline Milk lactose & 1.67 & 1.64 & 1.68 & 0.10 \\
\hline Milk SNF & 3.02 & 2.99 & 3.05 & 0.14 \\
\hline \multicolumn{5}{|l|}{ Milk composition } \\
\hline Fat $(\%)$ & 3.81 & 3.67 & 3.85 & 0.15 \\
\hline Protein (\%) & 3.07 & 3.07 & 3.09 & 0.07 \\
\hline Lactose (\%) & 4.82 & 4.83 & 4.81 & 0.06 \\
\hline SNF $(\%)$ & 8.78 & 8.8 & 8.79 & 0.06 \\
\hline MUN (mg/dL) & 15.1 & 14.4 & 14.6 & 0.83 \\
\hline $\mathrm{SCC}\left(\times 10^{3} / \mathrm{mL}\right)$ & $72^{\mathrm{a}}$ & $59^{\mathrm{b}}$ & $71^{\mathrm{a}}$ & 20.0 \\
\hline
\end{tabular}

the associated immune responses. No previous study has examined the effects of exogenous $\beta$-mannanase on health aspects of cattle but supplementation of MOS has been shown to enhance immune responses to rotavirus in dry cows (Franklin et al., 2005) and maintain BCS of early lactating beef cows (Linneen et al., 2014). Furthermore, excessive immune responses, particularly adaptive responses, represent significant energy expenditure in mammals (Cutrera et al., 2010). Therefore, cows with lower SCC could spend less energy for immune functions than cows with greater SCC. Overall, our results warrant further investigation into immune responses for $\beta$-mannanase supplementation, particularly in early lactation, when cows are generally under considerable immune and energy challenges.

\section{Nutrient Digestibility and FCE}

Mean apparent total-tract digestibility of nutrients, apparently absorbed DM and OM, and FCE of treatments are given in Table 3. Compared with control, digestibility of DM, OM, and CP significantly decreased in cows fed LS diet $(P<0.05)$ but remained unaffected by HS diet. The digestibility of NDF, ADF, and starch were not significantly affected by $\beta$-mannanase supplementation. In agreement with our study, ATTD of DM and OM decreased, whereas NDF digestibility was unaffected in 6-mo-old goats fed the same $\beta$-mannanase enzyme as used here at a dose of $0.06 \%$ of DM (Lee et al., 2014). Peters et al. (2015) also reported that supplementation of 1,4- $\beta$-glucanase and 1,4- $\beta$-xylanase did not affect ruminal and total-tract digestibility of NDF and ADF in lactating dairy cows. In line with the present study, the CTCZYME $\beta$-mannanase at 
Table 4. Effect of $\beta$-mannanase supplementation on nitrogen $(\mathrm{N})$ partitioning and phosphorus $(\mathrm{P})$ excretion

\begin{tabular}{|c|c|c|c|c|}
\hline \multirow[b]{2}{*}{ Item } & \multicolumn{3}{|c|}{ Treatment $^{1}$} & \multirow[b]{2}{*}{ SEM } \\
\hline & Control & LS & HS & \\
\hline $\mathrm{N}$ intake $(\mathrm{g} / \mathrm{d})$ & $686^{\mathrm{a}}$ & $643^{\mathrm{b}}$ & $673^{\mathrm{a}}$ & 17.3 \\
\hline Fecal N (g/d) & 235 & 234 & 224 & 7.6 \\
\hline Fecal N (\% of $\mathrm{N}$ intake) & $34.3^{\mathrm{ab}}$ & $36.6^{\mathrm{a}}$ & $33.4^{\mathrm{b}}$ & 0.7 \\
\hline Urinary $N$ output $(\mathrm{g} / \mathrm{d})$ & 185 & 199 & 195 & 10.5 \\
\hline Urinary $\mathrm{N}$ output (\% of $\mathrm{N}$ intake) & 26.9 & 31.3 & 29.1 & 1.7 \\
\hline Fecal N + urinary N $(\mathrm{g} / \mathrm{d})$ & 419 & 432 & 419 & 14 \\
\hline Milk protein $\mathrm{N}+$ MUN $(\mathrm{g} / \mathrm{d})$ & 170 & 168 & 172 & 7.7 \\
\hline Retained N (g/d) & $97.0^{\mathrm{a}}$ & $42.3^{\mathrm{b}}$ & $81.0^{\mathrm{ab}}$ & 14 \\
\hline Manure P $(\mathrm{g} / \mathrm{d})$ & 77 & 79 & 75 & 2.4 \\
\hline
\end{tabular}

remained similar across all cows. Compared with cows in the control group, cows receiving LS tended to have greater urinary $\mathrm{N}$ excretions proportional to $\mathrm{N}$ intake $(P=0.86)$, even though they were expected to have less urinary $\mathrm{N}$ partitioning as they had incorporated more dietary $\mathrm{N}$ intake or apparently absorbed $\mathrm{N}$ to milk protein (Table 3 ). Perhaps $\beta$-mannanase supplementation reduced amino acid partitioning to tissue gain relative to the increased milk protein synthesis efficiency, as indicated by the less retained $\mathrm{N}$ of LS cows compared with control cows (Table 4). Bequette et al. (2001) demonstrated that infusion of insulin increased blood flow to the mammary glands compared with that to hind-leg in lactating dairy goats. $\beta$-Mannans, the substrates of $\beta$-mannanase, have been shown to inhibit insulin secretion in human (Morgan et al., 1985) and swine (Leeds et al., 1980). In the present study, a $\beta$-mannanase-induced insulin secretion might have enhanced amino acids uptake by the mammary gland compared with the other tissues. Thus, investigations into the relationships among $\beta$-mannanase, insulin, and $\mathrm{N}$ partitioning are warranted in future studies. Nonetheless, supplementation of $\beta$-mannanase did not change total $\mathrm{N}$ excreted in manure (g/cow per day), and did not affect manure phosphorus output, although exogenous $\beta$-mannanase has been shown to reduce manure phosphorus output in growing pigs (Lv et al., 2013). Adesogan et al. (2014) emphasized that giving animals a sufficiently long adaptation period is key to capturing the true effects of fibrolytic enzymes in ruminants. In our experiment, the majority of the responses remained unchanged over the sampling period (d 16 to 18), indicating that the responses to the enzyme supplementation had reached a steady state after 2 wk (data not shown). Potential carryover effects in crossover designs may make it more difficult to tease out true treatment effects. However, the nonsignificant period $\times$ treatment interactions (i.e., $P=0.42,0.23$,
0.63 , and 0.32 for OM digestibility, milk yield, FCE and SCC, respectively; data not shown) indicated negligible carryover effects, given that the treatment assignments were balanced (Tempelman, 2004). Nevertheless, studies with continuous designs for longer periods need to be conducted to validate the results in this experiment.

\section{CONCLUSIONS}

Supplementation of $\beta$-mannanase to a corn silage and alfalfa hay-based TMR at a dose of $0.1 \%$ of DM increased milk yield per kilogram of DM and milk protein yield per kilogram of $\mathrm{CP}$ intake, and decreased SCC in milk of lactating dairy cows. Supplementation of $\beta$-mannanase at $0.2 \%$ of $\mathrm{DM}$ did not have a significant effect on any of these responses. Apparent total-tract digestibility of DM, OM, and CP decreased in response to the $0.1 \% \mathrm{DM}$ dose but were not affected at the $0.2 \%$ dose. Dietary $\mathrm{N}$ partitioning to urinary $\mathrm{N}$ increased, whereas $\mathrm{N}$ retained in the body decreased only in response to the $0.1 \%$ DM dose. However, total manure $\mathrm{N}$ output (fecal $\mathrm{N}$ plus urinary $\mathrm{N}$ ) was similar across cows with and without $\beta$-mannanase supplementation. Therefore, when supplied at a $0.1 \%$ of DM, $\beta$-mannanase was able to improve $\mathrm{FCE}$ and reduce SCC without affecting manure $\mathrm{N}$ excretion. The role of $\beta$-mannanase supplementation may be more critical in early lactating cows, which are generally under significant metabolic and immune challenges. Further research is needed to assess the mechanism and longterm effect of $\beta$-mannanase enzyme in lactating dairy cows.

\section{ACKNOWLEDGMENTS}

This research was supported by CTC Bio Inc. (Seoul, South Korea). The authors acknowledge the Sesnon Endowment Fund of University of California, 
Davis. The authors are grateful to assistance provided by Jasmin Grey, Berta Santiago, Hugo Bonfa, Anna Naranjo, Doug Gisi, and Sharlie Folsom (University of California-Davis, Davis, CA).

\section{REFERENCES}

Adesogan, A. T., Z. X. Ma, J. J. Romero, and K. G. Arriola. 2014. Ruminant nutrition symposium: Improving cell wall digestion and animal performance with fibrolytic enzymes. J. Anim. Sci. 92:1317-1330.

Álvarez, G., J. M. Pinos-Rodríguez, J. G. Herrera, J. C. García, S. S. Gonzalez, and R. Bárcena. 2009. Effects of exogenous fibrolytic enzymes on ruminal digestibility in steers fed high fiber rations. Livest. Sci. 121:150-154.

AOAC International. 2000. Official Methods of Analysis. 17th ed. AOAC International, Arlington, VA.

Arndt, C., J. M. Powell, M. J. Aguerre, P. M. Crump, and M. A. Wattiaux. 2015. Feed conversion efficiency in dairy cows: Repeatability, variation in digestion and metabolism of energy and nitrogen, and ruminal methanogens. J. Dairy Sci. 98:3938-3950.

Banos, G., E. Wall, M. P. Coffey, A. Bagnall, S. Gillespie, G. C. Russell, and T. N. McNeilly. 2013. Identification of immune traits correlated with dairy cow health, reproduction and productivity. PLoS One 8:e65766.

Beauchemin, K. A., D. Colombatto, D. P. Morgavi, and W. Z. Yang. 2003. Use of exogenous fibrolytic enzymes to improve feed utilization by ruminants. J. Anim. Sci. 81:E37-E47.

Bequette, B. J., C. E. Kyle, L. A. Crompton, V. Buchan, and M. D. Hanigan. 2001. Insulin regulates milk production and mammary gland and hind-leg amino acid fluxes and blood flow in lactating goats. J. Dairy Sci. 84:241-255.

Boraston, A. B., D. N. Bolam, H. J. Gilbert, and G. J. Davies. 2004. Carbohydrate-binding modules: Fine-tuning polysaccharide recognition. Biochem. J. 382:769-781.

Bradley, A., and M. Green. 2005. Use and interpretation of somatic cell count data in dairy cows. In Pract. 27:310-315.

Broderick, G. A. 2003. Effects of varying dietary protein and energy levels on the production of lactating dairy cows1. J. Dairy Sci. $86: 1370-1381$.

Che, T. M. 2010. Effects of mannan oligosaccharide on immune function and disease resistance in pigs. Department of Animal Science, University of Illinois at Urbana-Champaign.

Chen, X. B., Y. K. Chen, M. F. Franklin, E. R. Orskov, and W. J. Shand. 1992. The effect of feed intake and body weight on purine derivative excretion and microbial protein supply in sheep. J. Anim. Sci. 70:1534-1542.

Cho, J. H., and I. H. Kim. 2013. Effects of beta-mannanase supplementation in combination with low and high energy dense diets for growing and finishing broilers. Livest. Sci. 154:137-143.

Cutrera, A. P., R. R. Zenuto, F. Luna, and C. D. Antenucci. 2010 Mounting a specific immune response increases energy expenditure of the subterranean rodent Ctenomys talarum (tuco-tuco): Implications for intraspecific and interspecific variation in immunological traits. J. Exp. Biol. 213:715-724.

Daskiran, M., R. G. Teeter, D. Fodge, and H. Y. Hsiao. 2004. An evaluation of endo-beta-D-mannanase (hemicell) effects on broiler performance and energy use in diets varying in beta-mannan content. Poult. Sci. 83:662-668.

Dea, I. C. M., and A. Morrison. 1975. Chemistry and interactions of seed galactomannans. Pages 241-312 in Advances in Carbohydrate Chemistry and Biochemistry. Vol. 31. R. S. Tipson and H. Derek, ed. Academic Press, San Diego, CA.

Dierick, N. A. 1989. Biotechnology aids to improve feed and feed digestion: Enzyme and fermentation. Arch. Tierernahr. 39:241-261.

Egger, S. F., G. S. Brown, L. S. Kelsey, K. M. Yates, L. J. Rosenberg, and J. E. Talmadge. 1996. Hematopoietic augmentation by a beta(1,4)-linked mannan. Cancer Immunol. Immunother. 43:195-205.
Fernando, S. C., H. T. Purvis 2nd, F. Z. Najar, L. O. Sukharnikov, C R. Krehbiel, T. G. Nagaraja, B. A. Roe, and U. Desilva. 2010. Rumen microbial population dynamics during adaptation to a highgrain diet. Appl. Environ. Microbiol. 76:7482-7490.

Ferreira, H. C., M. I. Hannas, L. F. T. Albino, H. S. Rostango, R. Neme, B. D. Faria, M. L. Xavier Jr., and L. N. Renno. 2016. Effect of the addition of beta-mannanase on the performance, metabolizable energy, amino acid digestibility coefficients, and immune functions of broilers fed different nutritional levels. Poult. Sci. $95: 1848-1857$

Forsberg, N. E., and Y. Wang. 2006. Nutrition and immunity in dairy cattle: Implications to hemorrhagic bowel syndrome. Proceedings of Prince Agri Products Inc. Summit. Accessed Aug. 18, 2016 http://www.poolecommunication.com/PrinceSummit2006/ Ruminant/DIM030906-FINAL.pdf.

Franco, P. F., H. M. Ferreira, and E. X. Filho. 2004. Production and characterization of hemicellulase activities from Trichoderma harzianum strain T4. Biotechnol. Appl. Biochem. 40:255-259.

Franklin, S. T., M. C. Newman, K. E. Newman, and K. I. Meek. 2005. Immune parameters of dry cows fed mannan oligosaccharide and subsequent transfer of immunity to calves. J. Dairy Sci. $88: 766-775$.

Gharaei, M. A., B. Dastar, A. H. Nameghi, G. H. Tabar, and M. S. Shargh. 2012. Effects of guar meal with and without beta-mannanas enzyme on performance and immune response of broiler chicks. Int. Res. J. Appl. Basic Sci. 3:2785-2793.

Goering, H. K., and P. J. Van Soest. 1970. Forage fiber analyses. Agriculture Handbook. Agricultural Research Service, USDA, Washington, DC.

Hall, M. B. 2009. Determination of starch, including maltooligosaccharides, in animal feeds: Comparison of methods and a method recommended for AOAC collaborative study. J. AOAC Int. 92:42-49.

Heinrichs, A. J., C. M. Jones, and B. S. Heinrichs. 2003. Effects of mannan oligosaccharide or antibiotics in neonatal diets on health and growth of dairy calves. J. Dairy Sci. 86:4064-4069.

Ibuki, M., K. Fukui, H. Kanatani, and Y. Mine. 2014. Anti-inflammatory effects of mannanase-hydrolyzed copra meal in a porcine model of colitis. J. Vet. Med. Sci. 76:645-651.

Jackson, M. E., D. M. Anderson, H. Y. Hsiao, G. F. Mathis, and D. W. Fodge. 2003. Beneficial effect of beta-mannanase feed enzyme on performance of chicks challenged with Eimeria sp. and Clostridium perfringens. Avian Dis. 47:759-763.

Kasikci, G., O. Cetin, E. B. Bingol, and M. Can Gunduz. 2012. Relations between electrical conductivity, somatic cell count, California Mastitis Test and some quality parameters in the diagnosis of subclinical mastitis in dairy cows. Turk. J. Vet. Anim. Sci. 36:49-55.

Kim, J. S., S. L. Ingale, S. H. Lee, K. H. Kim, J. H. Lee, and B. J. Chae. 2013. Effects of energy levels of diet and $\beta$-mannanase supplementation on growth performance, apparent total tract digestibility and blood metabolites in growing pigs. Anim. Feed Sci. Technol. 186:64-70.

Kong, C., J. H. Lee, and O. Adeola. 2011. Supplementation of $\beta$-mannanase to starter and grower diets for broilers. Can. J. Anim. Sci. 91:389-397.

Kweun, M. A., M. Lee, J. H. Choi, K. H. Cho, and K. H. Yoon. 2004. Cloning of a Bacillus subtilis WL-7 mannanase gene and characterization of the gene product. J. Microbiol. Biotechnol. 14:1295-1302.

Lascano, C. E., J. E. Carulla, and J. J. Vargas. 2011. Strategies for reducing methane emissions from ruminants. Rev. Bras. Geog. Fisica 6:1315-1335

Lawal, T. E., E. A. Lyayi, B. A. Adeniyi, and O. A. Adaramoye. 2010. Biodegradation of palm kernel cake with multienzyme complexes from fungi and its feeding value for broilers. Int. J. Poult. Sci. 9:695-701.

Lee, J.-J., J. Seo, J. K. Jung, J. Lee, J.-H. Lee, and S. Seo. 2014. Effects of $\beta$-mannanase supplementation on growth performance, nutrient digestibility, and nitrogen utilization of Korean native goat (Capra hircus coreanae). Livest. Sci. 169:83-87. 
Leeds, A. R., S. S. Kang, A. G. Low, and I. E. Sambrook. 1980. The pig as a model for studies on the mode of action of guar gum in normal and diabetic man. Proc. Nutr. Soc. 39:44A.

Linneen, S. K., G. L. Mourer, J. D. Sparks, J. S. Jennings, C. L. Goad, and D. L. Lalman. 2014. Effects of mannan oligosaccharide on beef-cow performance and passive immunity transfer to calves. Prof. Anim. Sci. 30:311-317.

Lv, J. N., Y. Q. Chen, X. J. Guo, X. S. Piao, Y. H. Cao, and B. Dong. 2013. Effects of supplementation of $\beta$-mannanase in corn-soybean meal diets on performance and nutrient digestibility in growing pigs. Asian-australas. J. Anim. Sci. 26:579-587.

Mendoza, G. D., O. Loera-Corral, F. X. Plata-Perez, P. A. HernandezGarcia, and M. Ramirez-Mella. 2014. Considerations on the use of exogenous fibrolytic enzymes to improve forage utilization. Scientific World Journal 2014:247437.

Middleton, J. R., D. Hardin, B. Steevens, R. Randle, and J. W. Tyler. 2004. Use of somatic cell counts and California Mastitis Test results from individual quarter milk samples to detect subclinical intramammary infection in dairy cattle from a herd with a high bulk tank somatic cell count. J. Am. Vet. Med. Assoc. 224:419-423.

Mok, C. H., J. H. Lee, and B. G. Kim. 2013. Effects of exogenous phytase and $\beta$-mannanase on ileal and total tract digestibility of energy and nutrient in palm kernel expeller-containing diets fed to growing pigs. Anim. Feed Sci. Technol. 186:209-213.

Moreira, L. R. S., and E. X. F. Filho. 2008. An overview of mannan structure and mannan-degrading enzyme systems. Appl. Microbiol. Biotechnol. 79:165-178.

Morgan, L. M., J. A. Tredger, A. Madden, P. Kwasowski, and V. Marks. 1985. The effect of guar gum on carbohydrate-, fat- and protein-stimulated gut hormone secretion: Modification of postprandial gastric inhibitory polypeptide and gastrin responses. Br. J. Nutr. 53:467-475.

Mussini, F. J., C. A. Coto, S. D. Goodgame, C. Lu, A. J. Karimi, J. H. Lee, and P. W. Waldroup. 2011. Effect of a $\beta$-mannanase on nutrient digestibility in corn-soybean meal diets for broiler chicks. Int. J. Poult. Sci. 10:774-777.

Nakai, Y., M. Nakatani, T. Ando, T. Inamoto, and K. Ogimoto. 1994. Degradation of $\beta$-mannan by rumen bacteria. Nihon Chikusan Gakkaiho 65:443-446.

Niu, M., J. A. D. R. N. Appuhamy, A. Leytem, R. Dungan, and E. Kebreab. 2016. Effect of dietary crude protein and forage contents on enteric methane emissions and nitrogen excretion from dairy cows simultaneously. Anim. Prod. Sci. 56:312-321.

NRC. 1989. Nutrient Requirements of Dairy Cattle. 6th rev. ed. Natl. Acad. Press, Washington, DC.

Nyman, A. K., U. Emanuelson, and K. P. Waller. 2016. Diagnostic test performance of somatic cell count, lactate dehydrogenase, and $\mathrm{N}$-acetyl-beta-D-glucosaminidase for detecting dairy cows with intramammary infection. J. Dairy Sci. 99:1440-1448.

Oviedo-Boyso, J., J. J. Valdez-Alarcon, M. Cajero-Juarez, A. OchoaZarzosa, J. E. Lopez-Meza, A. Bravo-Patino, and V. M. Baizabal-Aguirre. 2007. Innate immune response of bovine mammary gland to pathogenic bacteria responsible for mastitis. J. Infect. 54:399-409.

Peters, A., U. Meyer, and S. Dänicke. 2015. Effect of exogenous fibrolytic enzymes on performance and blood profile in early and midlactation Holstein cows. Anim. Nutr. 1:229-238.

Pettey, L. A., S. D. Carter, B. W. Senne, and J. A. Shriver. 2002. Effects of beta-mannanase addition to corn-soybean meal diets on growth performance, carcass traits, and nutrient digestibility of weanling and growing-finishing pigs. J. Anim. Sci. 80:1012-1019.

Rainard, P., P. Cunha, and F. B. Gilbert. 2016. Innate and adaptive immunity synergize to trigger inflammation in the mammary gland. PLoS One 11:e0154172.

Rainard, P., P. Cunha, M. Ledresseur, C. Staub, J. L. Touze, F. Kempf, F. B. Gilbert, and G. Foucras. 2015. Antigen-specific mammary in- flammation depends on the production of IL-17a and IFN-gamma by Bovine CD4+ T lymphocytes. PLoS One 10:e0137755.

Rivas, A. L., R. Tadevosyan, F. W. Quimby, and D. H. Lein. 2002. Blood and milk cellular immune responses of mastitic non-periparturient cows inoculated with Staphylococcus aureus. Can. J. Vet. Res. 66:125-131.

Romero, J. J., E. G. Macias, Z. X. Ma, R. M. Martins, C. R. Staples, K. A. Beauchemin, and A. T. Adesogan. 2016. Improving the performance of dairy cattle with a xylanase-rich exogenous enzyme preparation. J. Dairy Sci. 99:3486-3496.

Saenphoom, P., J. B. Liang, Y. W. Ho, T. C. Loh, and M. Rosfarizan. 2013. Effects of enzyme treated palm kernel expeller on metabolizable energy, growth performance, villus height and digesta viscosity in broiler chickens. Asian-australas. J. Anim. Sci. 26:537-544.

Seo, J., J. Park, J. Lee, J.-H. Lee, J.-J. Lee, D. K. Kam, and S. Seo 2016. Enhancement of daily gain and feed efficiency of growing heifers by dietary supplementation of $\beta$-mannanase in Hanwoo (Bos taurus coreanae). Livest. Sci. 188:21-24.

Sharma, N., N. K. Singh, and M. S. Bhadwal. 2011. Relationship of somatic cell count and mastitis: An overview. Asian-australas. J. Anim. Sci. 24:429-438

Sunna, A., M. D. Gibbs, and P. L. Bergquist. 2001. Identification of novel beta-mannan- and beta-glucan-binding modules: Evidence for a superfamily of carbohydrate-binding modules. Biochem. J. 356:791-798.

Swanson, K. S., C. M. Grieshop, E. A. Flickinger, L. L. Bauer, H. P. Healy, K. A. Dawson, N. R. Merchen, and G. C. Fahey Jr.. 2002. Supplemental fructooligosaccharides and mannanoligosaccharides influence immune function, ileal and total tract nutrient digestibilities, microbial populations and concentrations of protein catabolites in the large bowel of dogs. J. Nutr. 132:980-989.

Tailford, L. E., V. M. Ducros, J. E. Flint, S. M. Roberts, C. Morland D. L. Zechel, N. Smith, M. E. Bjornvad, T. V. Borchert, K. S. Wilson, G. J. Davies, and H. J. Gilbert. 2009. Understanding how diverse beta-mannanases recognize heterogeneous substrates. Biochemistry 48:7009-7018.

Tempelman, R. J. 2004. Experimental design and statistical methods for classical and bioequivalence hypothesis testing with an application to dairy nutrition studies. J. Anim. Sci. 82(E-Suppl.):E162E172.

Van Soest, P. J., J. B. Robertson, and B. A. Lewis. 1991. Methods for dietary fiber, neutral detergent fiber, and nonstarch polysaccharides in relation to animal nutrition. J. Dairy Sci. 74:3583-3597.

Wu, G., M. M. Bryant, R. A. Voitle, and D. A. Roland Sr.. 2005. Effects of beta-mannanase in corn-soy diets on commercial leghorns in second-cycle hens. Poult. Sci. 84:894-897.

Yang, W. Z., K. A. Beauchemin, and L. M. Rode. 2000. A comparison of methods of adding fibrolytic enzymes to lactating cow diets. J. Dairy Sci. 83:2512-2520.

Yang, Y., P. A. Iji, A. Kocher, L. L. Mikkelsen, and M. Choct. 2008. Effects of mannanoligosaccharide and fructooligosaccharide on the response of broilers to pathogenic Escherichia coli challenge. Br. Poult. Sci. 49:550-559

Yoon, S. Y., Y. X. Yang, P. L. Shinde, J. Y. Choi, J. S. Kim, Y. W Kim, K. Yun, J. K. Jo, J. H. Lee, S. J. Ohh, I. K. Kwon, and B. J. Chae. 2010. Effects of mannanase and distillers dried grain with solubles on growth performance, nutrient digestibility, and carcass characteristics of grower-finisher pigs. J. Anim. Sci. 88:181-191.

Yu, A. B., G. Q. Zhao, and Y. J. Huo. 2011. Relationship between parity and cellular composition of somatic cells in milk of Chinese Holstein cows. J. Anim. Vet. Adv. 10:2067-2073.

Zangiabadi, H., and M. Torki. 2010. The effect of a $\beta$-mannanase-based enzyme on growth performance and humoral immune response of broiler chickens fed diets containing graded levels of whole dates. Trop. Anim. Health Prod. 42:1209-1217. 